\title{
Dorota Jaźwińska
}

Wyższa Szkoła Bankowa w Poznaniu

e-mail: dorota.jazwinska@wsb.poznan.pl

\section{ROZWÓJ PRZYSZLYCH POKOLEŃ \\ I JEGO ZRÓWNOWAŻENIE}

\section{DEVELOPMENT OF FUTURE GENERATIONS AND ITS SUSTAINABILITY}

DOI: $10.15611 / \mathrm{pn} .2018 .51 .05$

JEL Classification: M21, Q5, O44

Streszczenie: W artykule poruszono zagadnienia dotyczące przyszłości młodego pokolenia w aspekcie zrównoważonego rozwoju. Koncepcja zrównoważonego rozwoju nabiera coraz większego znaczenia. Działania zgodne z tą ideą są zauważalne w różnych dziedzinach życia i w różnych rejonach świata. W niniejszym opracowaniu została poruszona swoista różnorodność podejść i reakcji na problemy obecnego i przyszłych pokoleń. Celem badań własnych, przeprowadzonych metodą CAWI, było m.in. zdiagnozowanie zagadnień uznanych, według opinii młodego pokolenia, za szanse oraz za zagrożenia dla rozwoju cywilizacyjnego. W badaniu (pilotażowym) uczestniczyło 144 respondentów w wieku do 30 lat - w większości osoby studiujące (najwięcej z kierunku zarządzanie). Badania wykazały, że młodzi ludzie są świadomi, iż wiele zagadnień należy rozpatrywać jako zjawiska połączone (interdyscyplinarność). Respondenci zdają sobie sprawę z zagrożeń, jakie niesie rozwój cywilizacyjny. Widzą szansę na rozwój wynikającą przede wszystkim z ludzkiej kreatywności.

Słowa kluczowe: zrównoważony rozwój, przyszłe pokolenia, wspólna wartość, równowaga między pracą a życiem.

Summary: The article deals with issues concerning the future of the young generation in the aspect of sustainable development. The concept of sustainable development is becoming more and more important. This study presents the problems of current and future generations. The aim of the CAWI research was to answer the question, which issues were an opportunity according to the opinion of the young generation and which were a threat to the development of civilization and which elements of sustainable development were the most important. 144 respondents aged up to 30 participated in the (pilot) study. Research has shown that young people are aware that many issues should be seen as combined phenomena (interdisciplinary). Respondents are aware of the threats posed by the development of civilization. They see a chance for development resulting primarily from human creativity.

Keywords: sustainable development, future generations, shared value, work-life balance. 


\section{Wstęp}

Temat zrównoważonego rozwoju jest popularyzowany od momentu pojawienia się Raportu Brundtland (1987). W międzyczasie wprowadzono szereg aktów prawnych, wytycznych, norm oraz koncepcji, które mają pomóc w rozwoju różnorodnych organizacji, nie pociągając za sobą niekorzystnych skutków, niosących zagrożenie dla środowiska i zdrowia ludzi. Organizacje deklarujące chęć sprostania wymogom zrównoważonego rozwoju podejmują działania, które przynoszą im wymierną korzyść. Taką korzyścią mogą być m.in. budowa kapitału społecznego oraz dbanie o wspólne dobro, jakim jest środowisko - dawca zasobów. Rozwój zgodnie z ideą zrównoważonego rozwoju uwarunkowany jest wieloma czynnikami. Należą do nich m.in. proces edukacji i budowa postaw proekologicznych, zrównoważona produkcja i konsumpcja, odpowiedzialność społeczna (w tym etyka, uczciwość), gospodarowanie zasobami naturalnymi i energią, obieg zamknięty (gospodarka cyrkularna), zarządzanie różnorodnością oraz równe szanse rozwoju. Odpowiedzialność rozumiana jako dbanie o innych lub o określone dobra może jedynie wzmacniać kierunek działań obecnego pokolenia oraz jego następców. Definicja zrównoważonego rozwoju odnosi się do przyszłości. Jej wspólne kreowanie wymaga współpracy wielu grup interesariuszy oraz korzystania z dostępnych rozwiązań sprzyjających zrównoważonemu rozwojowi. Celem artykułu jest przedstawienie zagadnień uznanych za szanse dla zrównoważonego rozwoju oraz będące dla niego zagrożeniem, jak również najważniejszych elementów dotyczących zrównoważonego rozwoju. Pytania badawcze zadano respondentom w wieku do 30 lat. Wyniki przeprowadzonych badań własnych zamieszczono w końcowej części artykułu.

\section{Problematyka zrównoważonego rozwoju}

Zrównoważony rozwój, rozumiany jako troska o obecne i przyszłe pokolenia [Waas $i$ in. Verbruggen, Wright 2010, s. 631], ukształtował pogląd na wzrost gospodarczy, mówiący o tym, że działania prośrodowiskowe i prospołeczne są nie mniej ważne od aspektów ekonomicznych. W roku 1987 Światowa Komisja ds. Środowiska i Rozwoju pod przewodnictwem Gro Harlem Brundtland przygotowała Raport „Nasza Wspólna Przyszłość" [Williams, Millington 2004, s. 99-100; Dubiński 2013, s. 1; Jaźwińska 2016, s. 154], który wskazał główne cele mające ten efekt synergii wzmocnić. Wśród nich znajdują się m.in.: ochrona i przywracanie bogactw naturalnych [Dubiński 2013, s. 1], zmiana jakości wzrostu gospodarczego, profile technologiczne oraz zaspokajanie egzystencjalnych potrzeb ludzkości (w tym praca i energia); [Jaźwińska 2017, s. 98]. W Raporcie zdefiniowano zrównoważony rozwój jako taki, który odpowiada potrzebom teraźniejszości bez pogarszania zdolności rozwojowej przyszłych pokoleń [Report... 1987, s. 42].

Istotną kwestią staje się zasada racjonalnego gospodarowania, uwzględniającego procesy rozwojowe w skali globalnej. Ważne jest wdrażanie niskoemisyjnych 
lub bezemisyjnych technologii [Wyrwicka, Jaźwińska 2015, s. 5855], co ma uzasadnienie w zapobieganiu nadmiernej emisji czy burzeniu równowagi w środowisku prewencja zamiast naprawy oraz edukacja i kształtowanie świadomości ekologicznej [Górka 2007, s. 12]. Nadal poszukuje się nowych modeli konsumpcji, wzorców etycznych i moralnych [Górka 2007, s. 13], jak również modeli biznesu, które umożliwiałyby zrównoważony i trwały rozwój. J. Sachs [2012, s. 2211] pisze wprost, że świat będzie potrzebował nowych technologii i nowych sposobów organizacji człowieka - działalności łączącej poprawę standardów życia z imperatywami ekologicznymi. Zmiany technologiczne i społeczne będą najważniejsze - zarówno w krajach bogatych, jak i biednych.

G. Leśniak-Łebkowska zaznacza, że w zarządzaniu strategicznym może to być era stabilnego i bezpiecznego rozwoju, tworzącego wartość dla interesariuszy. Słusznie zauważa, że sam rozwój gospodarczy nie jest gwarancją poczucia dobrobytu [Leśniak-Łebkowska 2017, s. 52]. Wobec wyzwań rozwojowych i pojawiających się kryzysów w skali globalnej znaczenia nabierają czynniki miękkie, takie jak potencjał intelektualny, wiedza, kompetencje, motywacja czy emocje. Trwałość postępu powinien warunkować kapitał moralny - trzon kapitału społecznego, którego podstawą są zaufanie i budowa relacji. Dzięki zaufaniu i relacjom możliwe są innowacje, współpraca oraz odpowiedzialność za osiągane wyniki [Leśniak-Łebkowska 2017, s. 51].

Oprócz poszukiwania innowacji proponuje się podejmowanie działań inicjujących pożądane zmiany - ambicje rozwojowe społeczeństwa określane jako „rewolucja przetrwania" [Kramer 2011, s. 5]. Wśród takich działań wspomnieć można wymienione przez autorów „Granic wzrostu” (D.H. Meadows, D.L. Meadows, J. Randers, W.W. Behrens - przyp. aut.) redukcję działań materialnych (wzrost zapewniający ekologiczną trwałość systemu i rozwój społeczny) oraz wzrost odpowiedzialny, zapewniający dobrobyt, ochronę zdrowia, równość społeczną, eliminację ubóstwa i głodu [Kramer 2011, s. 5], równowagę ekologiczną i rozwijanie globalnego partnerstwa na rzecz rozwoju [www.un.org 2017]. Ruch obywatelski zdolny do dokonania (ekologicznej) rewolucji powinien mieć cechy będące wyróżnikiem nowego społeczeństwa. J. Kramer [2011, s. 5-6] przywołuje pięć cech wyróżniających: 1) wizjonerstwo (myślenie długookresowe), 2) sieciowość (rozwijanie stosunków społecznych dzięki sieciom informacyjnym), 3) prawdę (podstawa realizmu oceny zdarzeń i tendencji rozwojowych), 4) powszechną edukację (wprowadzenie poprzednich zasad) oraz 5) miłość (norma moralna związana z przyjaznym nastawieniem, zrozumieniem i współdziałaniem). Istotne elementy postępu cywilizacyjnego związane są z bardzo szybkim rozwojem technologii (m.in. informatycznych czy informacyjnych), cyfryzacji, usług on-line [Judy, D'Amico 1997, s. 46] oraz tworzeniem robotów zastępujących człowieka czy samochodów z robokierowcami (samojeżdżące samochody). Firmy takie jak Amazon, UPS i Google testują drony do dostarczania przesyłek. W medycynie wykorzystuje się roboty operacyjne zastępujące chirurgów [Ross 2017, s. 57-60]. Przyszłość ma, z jednej strony, odciążyć człowieka od wykonywania stresującej lub 
ciężkiej pracy, z drugiej, tym samym pozbawia go szansy na pracę w ogóle. Jak zatem będzie wyglądała przyszłość? R. Rohatyński [2017, s. 117] zaznacza, że ogniwem przewidywania przyszłości oraz tworzenia planów jest i tak człowiek. R. Kiyosaki [Kiyosaki, Lechter 2001, s. 58-65] zwraca uwagę na zmiany przepływu pieniędzy czy finansowania $w$ epoce informacyjnej. Pojawia się też kwestia związana z systemem emerytalnym - może zabraknąć środków na wypłacanie świadczeń (problem zauważany nie tylko w Stanach Zjednoczonych, ale również w Polsce).

\section{Zrównoważony rozwój - zagrożenia i szanse}

Istotnym aspektem $\mathrm{w}$ trakcie rozważania o przyszłości są zarówno szanse, jak i zagrożenia, które pojawiają się wraz z rozwojem cywilizacyjnym. Trwały i zrównoważony rozwój powinien zapewnić preferowaną jakość życia, m.in. wyrównanie szans rozwoju, dostęp do naturalnych bogactw, równouprawnienie oraz fair trade (sprawiedliwy handel). Porusza się zagadnienia związane ze zrównoważoną konsumpcją i produkcją, która jest jednym z priorytetów strategii Unii Europejskiej w sprawie jakości życia mieszkańców Wspólnoty. Zrównoważona konsumpcja rozumiana jest jako taka, której poziom jednocześnie zaspokaja podstawowe potrzeby oraz pomaga osiągnąć lepszą jakość życia za pomocą dóbr niwelujących presję na środowisko we wszystkich etapach produkcji, zachowując niezmienność zasobów dla kolejnych pokoleń [Łuczka 2016, s. 137]. J. Dubiński [2013, s. 5] wskazuje na znaczenie dostępu do złóż surowców, które są istotne dla rozwoju wielu nowych technologii.

Ograniczona dostępność tych surowców (nierównomierny rozkład geograficzny) determinuje politykę surowcową państw, które nimi dysponują. Tym samym kraje mniej zasobne surowcowo spychane są na margines rozwoju gospodarczego i cywilizacyjnego, co stanowi zagrożenie dla ich rozwoju. Przykładem są surowce energetyczne: 1,3 mld ludzi (na obecnie ponad $7 \mathrm{mld}$ ) na świecie nie posiada dostępu do energii elektrycznej, do gotowania natomiast 2,7 mld wykorzystuje biomasę. Stan ten można określić jako brak dostępu do określonych surowców, brak rozpoznania w tym zakresie lub zbyt wysokie koszty pozyskiwania surowców [Dubiński 2013, s. 5].

Kolejnym zagadnieniem i zagrożeniem jest ubóstwo. Ludzie żyjący w skrajnej biedzie nie mogą zaspokoić podstawowych potrzeb pozwalających na przetrwanie - pojawia się problem głodu, brak dostępu do wody pitnej czy opieki zdrowotnej. Ubóstwo umiarkowane to brak dostępu do świadczeń edukacyjnych, kultury czy opieki zdrowotnej wysokiej jakości [Teneta-Skwiercz 2017 za Sachs 2012, s. 49]. J. Sachs stwierdza, że główna strategia w eliminacji skrajnego ubóstwa powinna polegać na rozszerzeniu zasięgu kluczowych technologii (w tym dostępności do lekarstw, diagnostyki, dostępu do internetu) z wysoko- i średniodochodowych gospodarek do gospodarek o niskich dochodach [Sachs 2012, s. 2211].

Ten proces można już zaobserwować. Kraje afrykańskie, zmagając się z problemami związanymi z ubóstwem i głodem, dokonują jednocześnie radykalnych zmian 
rozwojowych, wykorzystując m.in. technologie informatyczne (program Apps4Africa $\left.^{1}\right)$ [Ross 2017, s. 348-349].

Rozwinięte gospodarki dostarczają wstrząsów i zaburzeń o niespotykanym charakterze i pochodzeniu. Ich źródłem, jak i ofiarami zarazem (zagrożenie dla egzystencji), są młodzi ludzie rozpoczynający karierę zawodową. Przykładem może być Europa Zachodnia - część młodego pokolenia szuka stałej pracy, nie ma możliwości ukierunkowania kariery, napotyka trudności w odnalezieniu się w otaczającej rzeczywistości [Gawlik 2015, s. 2].

Kolejny aspekt stanowi zróżnicowanie kulturowe. W każdej kulturze występują wierzenia i religie, które od wieków odgrywają ważną rolę w życiu społecznym i etycznej orientacji jednostek [Kot 2003, s. 157]. Fanatyzm niektórych odłamów religii stwarza realną groźbę dla całego świata. Według T. Stefanowicza [1996, s. 56] zdobycie przez kraje muzułmańskie broni nuklearnej to kwestia czasu. Pojawiające się akty terroryzmu i samobójstw nasiliły się w ostatnich latach, co zdaje się oznaczać, iż owa sugestia staje się coraz bardziej możliwa. Statystyki wskazują, że w roku 2015 w wyniku ataków terrorystycznych w Europie (Francja) zginęło 137 osób, a 300 zostało rannych. W roku 2016 (Azja, Europa, Ameryka, Afryka) liczba ofiar wzrosła do 927 zabitych i 2169 rannych. Rok 2017 (Afryka, Azja, Europa) zamknął się stratą 196 zabitych i 468 rannych [https://wiadomosci.onet.pl...]. Można jednocześnie zaobserwować miejsca rozprzestrzeniania się fali terroryzmu - od Azji przez Afrykę aż po Amerykę i Europę. Poczucie bezpieczeństwa obywateli zostało zachwiane praktycznie na całym świecie.

Dążenie do zaspokajania potrzeb, poprawy dobrobytu oraz bogacenia się jest naturalne i nie ma ograniczeń, jeśli nie jest hamowne kulturowo, przez nakazy religijne [Stefanowicz 1996, s. 56] lub terroryzm i inne akty przemocy.

Oprócz wymienionych zagrożeń uniemożliwiających lub spowalniających zrównoważony rozwój pojawiają się szanse, które sprzyjają równoczesnej realizacji celów społecznych, ekologicznych i ekonomicznych, w szczególności podmiotom gospodarczym. Jedną z takich szans upatruje się w stosowanych koncepcjach zarządzania, które z założenia powinny ułatwiać zrównoważony rozwój. W roku 2007 Komisja Europejska przyjęła definicję społecznej odpowiedzialności biznesu (Corporate Social Responsibility - CSR) jako koncepcję, w ramach której firmy integrują problemy społeczne i środowiskowe w swoich działaniach biznesowych i interakcji zainteresowanych stron. Z kolei Organizacja Narodów Zjednoczonych w 2007 r. przyjęła definicję określającą CSR jako ogólny wkład biznesu na rzecz zrównoważonego rozwoju [Keith 2008, s. 21]. Aktualna definicja opublikowana przez Komisję Europejską określa społeczną odpowiedzialność biznesu jako „odpowiedzialność przedsiębiorstw za ich wpływ na społeczeństwo" [Komunikat KE... 2011, s. 7]. W tym miejscu można zadać pytanie o profil działalności przedsiębiorstw - pytanie o za-

${ }^{1}$ Program Apps4Africa ma na celu zapewnienie nowo powstałym innowacyjnym firmom z terenu Afryki dostępu do środków finansowych na uruchomienie i rozwój biznesu, jak również umożliwia korzystanie z telefonii komórkowej - w Afryce jest to ok. 650 mln użytkowników [Ross 2017, s. 349]. 
spokajanie potrzeb, które wywołują chaos, strach czy agresję, a tym samym stają się zagrożeniem dla innych.

W roku 2011 M.E. Porter i M.R. Kramer użyli pojęcia Creating Shared Value CSV (kreowanie wspólnej wartości) oznaczającego nowe podejście do społecznej odpowiedzialności. Według Portera i Kramera kreowanie wspólnej wartości jest nową drogą do osiągnięcia sukcesu gospodarczego [Porter, Kramer 2011, s. 4]. Tworzenie wspólnej wartości koncentruje się na identyfikacji powiązań między rozwojem ekonomicznym a społecznym. M.E. Porter i M.R. Kramer dodają, że polityka i działania firmy powinny prowadzić do poprawy warunków ekonomicznych i społecznych w społecznościach, w których ona funkcjonuje [Kozioł, Wojtowicz 2016, s. 166]. Tworząc wartość gospodarczą, przedsiębiorstwa kreują także wartość społeczną [Więcek-Janka i in. 2017, s. 445]. Wspólne działania różnych grup interesariuszy mogą być szansą na osiągnięcie zrównoważonego rozwoju.

Standardy jakości życia (szczególnie w wymiarze niematerialnym) kształtowane są pod wpływem tradycji, religii, kultury i edukacji. Standardy materialne zależą od systemu społeczno-gospodarczego i zamożności danego państwa [Borkowska 2010, s. 5]. Działania w tym zakresie mogą się przyczynić do zrównoważonego rozwoju. Pomocne stają się systemy wiedzy [Cash i in. 2003, s. 8090], również o zrównoważonym rozwoju czy odpowiedzialności za prowadzoną działalność i skutki podejmowanych decyzji. Wykorzystanie wiedzy na ten temat stwarza szansę na rozwój zgodny z wytycznymi Raportu Brundtland.

Najnowsze teorie strategicznego wykorzystania społecznej odpowiedzialności biznesu podkreślają rolę asymetrii informacyjnej i tego, w jaki sposób CSR może zostać włączony do strategii różnicowania produktów firmy [Tai, Chuang 2014, s. 120]. D. Matten i J. Moon [2004, s. 324] wskazują, że koncepcja CSR jest dla korporacji wyzwaniem w zakresie nabywania i rozwijania odpowiednich umiejętności i kompetencji. Pojawia się pytanie o rolę edukacji biznesowej: zapewnienia absolwentom umiejętności CSR, dostarczania edukacji CSR dla praktyków, specjalistycznej edukacji CSR dla przemysłu, badań mających na celu poszerzenie wiedzy na temat CSR [Matten, Moon 2004, s. 324].

Istotna z punktu widzenia jakości życia i w odniesieniu do koncepcji społecznej odpowiedzialności jest równowaga praca - życie (work-life balance). Równowaga pomiędzy pracą zawodową a życiem rodzinnym to zdolność do wypełniania zobowiązań zawodowych i rodzinnych. Równowaga związana z życiem zawodowym, oprócz relacji między pracą a funkcją pełnioną w rodzinie, obejmuje także rolę człowieka w innych dziedzinach jego życia. P. Delecta [2011, s. 187] zwraca uwagę na możliwość zachwiania równowagi przez konflikt wywołany stresem. Równowaga występuje wtedy, gdy spełniane są osobiste wymagania zarówno w pracy, jak i w życiu osobistym [Lockwood 2003, s. 2]. Według C. Riordan główną kwestią nie jest równe dzielenie czasu pomiędzy poszczególne przestrzenie, lecz efektywność relacji między życiem osobistym a pracą - zharmonizowanie pracy z innymi aspektami życia [www.hbrp.pl 2017]. Szansą na spełnianie kryteriów zrównoważonego rozwo- 
ju jest zachowanie równowagi psychofizycznej zasobów ludzkich, które podejmują trud, by postęp cywilizacyjny następował w sposób nienaruszający możliwości rozwojowych obecnym i przyszłym pokoleniom.

\section{Wyniki badań własnych}

Badania własne (metoda CAWI), pilotażowe, dotyczące postrzegania przez młodych ludzi aspektów zrównoważonego rozwoju, przeprowadzone zostały pod koniec listopada 2017 roku. Kwestionariusz ankiety skierowano do grupy Polaków poniżej 30. roku życia, którzy posiadali aktywną elektroniczną skrzynkę pocztową. Kwestionariusz ankiety składał się z czterech bloków tematycznych (pytania wielokrotnego wyboru), które dotyczyły: 1) elementów zrównoważonego rozwoju, 2) szans, 3) zagrożeń, 4) obaw. W badaniu wzięło udział 144 respondentów w wieku: poniżej 20 lat (17,5\%), 20-21 lat (25,9\%), 22-23 lat (26,6\%), 24-25 lat (18,9\%) i $26-30$ lat $(11,1 \%)$. Osoby w wieku $20-25$ lat stanowiły prawie $72 \%$ respondentów. Studia podjęło łącznie $82,6 \%$ ankietowanych.

Na rys. 1 przedstawiono odsetek wskazań, jakie uzyskały poszczególne elementy zrównoważonego rozwoju. Trzy aspekty zdecydowanie wysunęły się na prowadzenie: jakość życia (komfort, bezpieczeństwo i finanse), równowaga między pracą a życiem oraz relacje międzyludzkie - dwa pierwsze elementy uzyskały ex aequo $71,5 \%$, ostatni zaś $70,8 \%$ wskazań. Niemniej jednak pozostałe aspekty zrównowa-

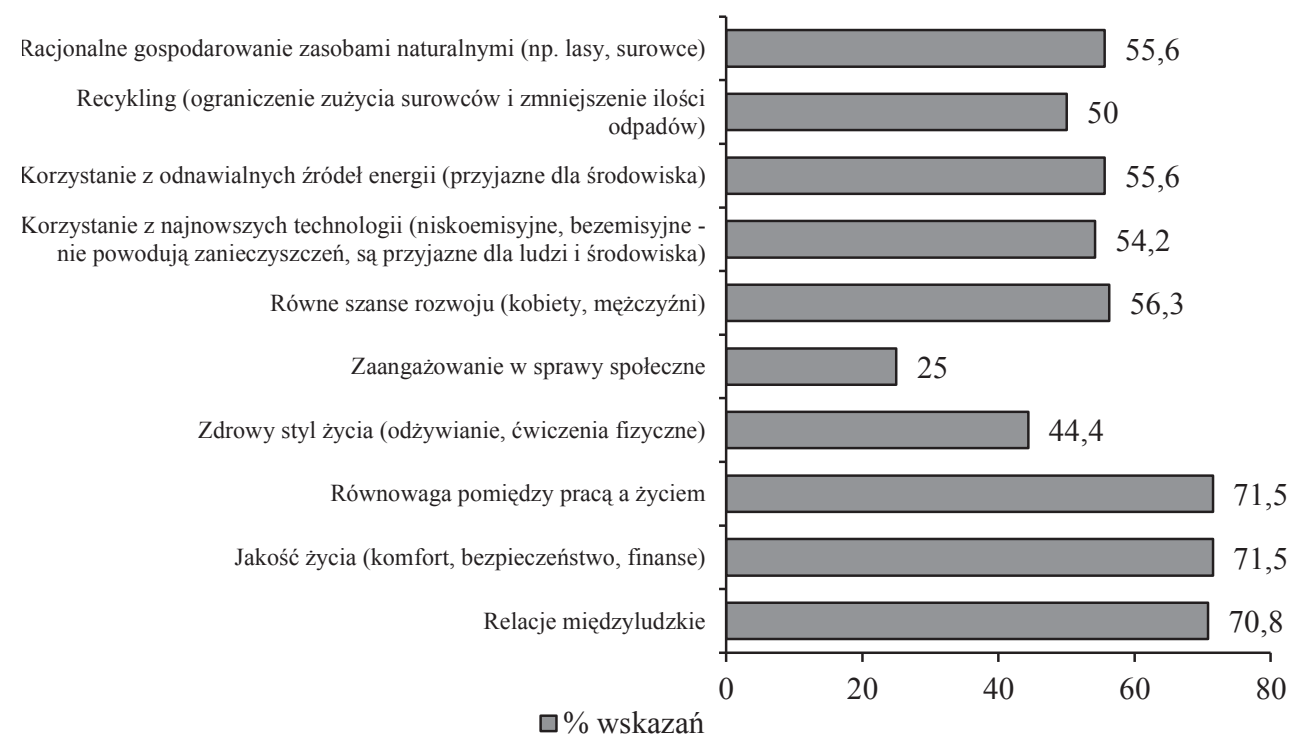

Rys. 1. Najważniejsze elementy zrównoważonego rozwoju

Źródło: opracowanie własne na podstawie wyników badań. 
żonego rozwoju również nie były ankietowanym obojętne - zdecydowana większość z nich uzyskała ponad 50\% wskazań.

W typowaniu zwyciężyły aspekty ekonomiczne. Najmniejszą ilość wskazań uzyskało angażowanie się w sprawy społeczne (25\%). Można wnioskować, że sprawy społeczne postrzegane są jako działania w ramach wolontariatu.

Szanse rozwojowe (rys. 2) stwarza, według respondentów, zdecydowanie ludzka kreatywność $(82,6 \%)$. Następne w kolejności są transfer wiedzy oraz społeczna odpowiedzialność (uczciwość, etyka). Dążenie do bezpieczeństwa nie jest natomiast postrzegane jako szansa na zrównoważony rozwój - uzyskało tylko $21,5 \%$ wskazań (najmniej). Wyniki wskazują na ogromną rolę człowieka w dążeniu do rozwoju, co potwierdzają również opracowania naukowe na ten temat. Człowiek jako twórca jest odpowiedzialny za produkowane przez siebie dobra.

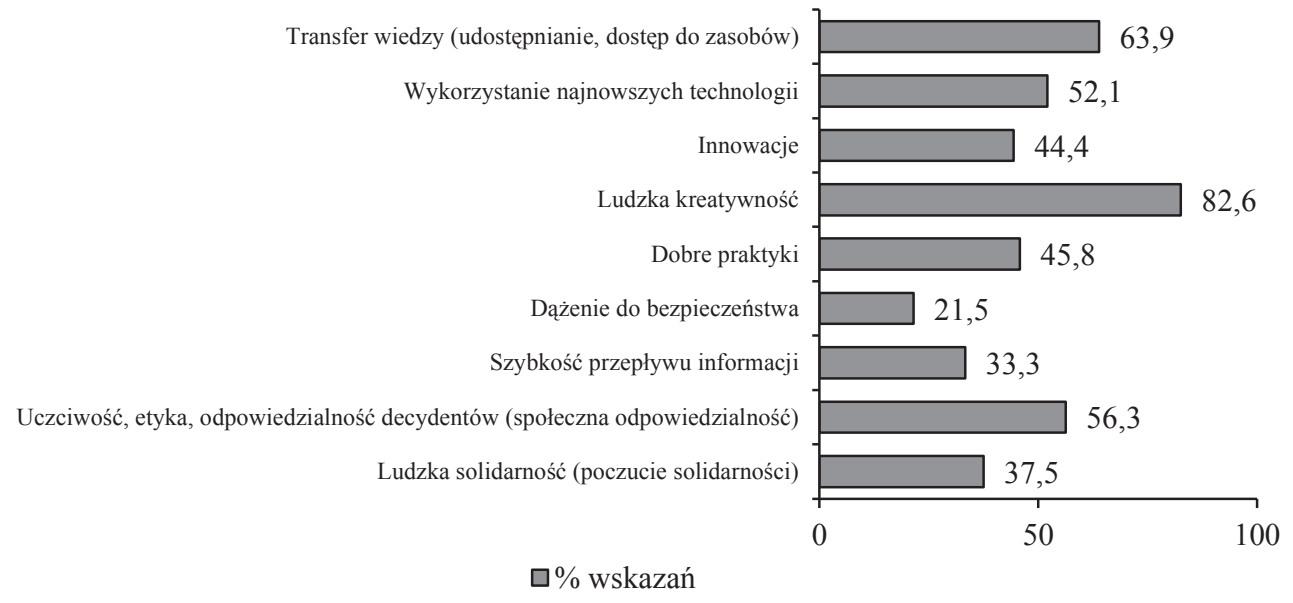

Rys. 2. Najważniejsze szanse rozwojowe

Źródło: opracowanie własne na podstawie wyników badań.

Terroryzm, konflikty religijne, brak odpowiedzialności decydentów za skutki decyzji oraz konflikty na tle zbrojnym postrzegane są jako największe zagrożenia dla zrównoważonego rozwoju i uzyskały zbliżoną liczbę wskazań (rys. 3). Niesprawiedliwy handel uzyskał najmniej głosów (20,8\%). Rozkład procentowy wskazań jest interesujący ze względu na brak powiązania z poprzednim pytaniem, które odnosiło się do szans rozwojowych - dążenie do bezpieczeństwa. Respondenci uznali dążenie do bezpieczeństwa za najmniej istotne dla szans rozwojowych, natomiast jako zagrożenie wskazali terroryzm i konflikty religijne. Jako jeden z dwóch najważniejszych elementów zrównoważonego rozwoju ankietowani wskazali jakość życia (komfort, bezpieczeństwo, finanse).

Młodzi ludzie najbardziej obawiają się utraty zdrowia $(61,8 \%)$ i płacy na niskim poziomie $(47,9 \%)$. Pozostałe wymienione zagadnienia uzyskały podobną liczbę 


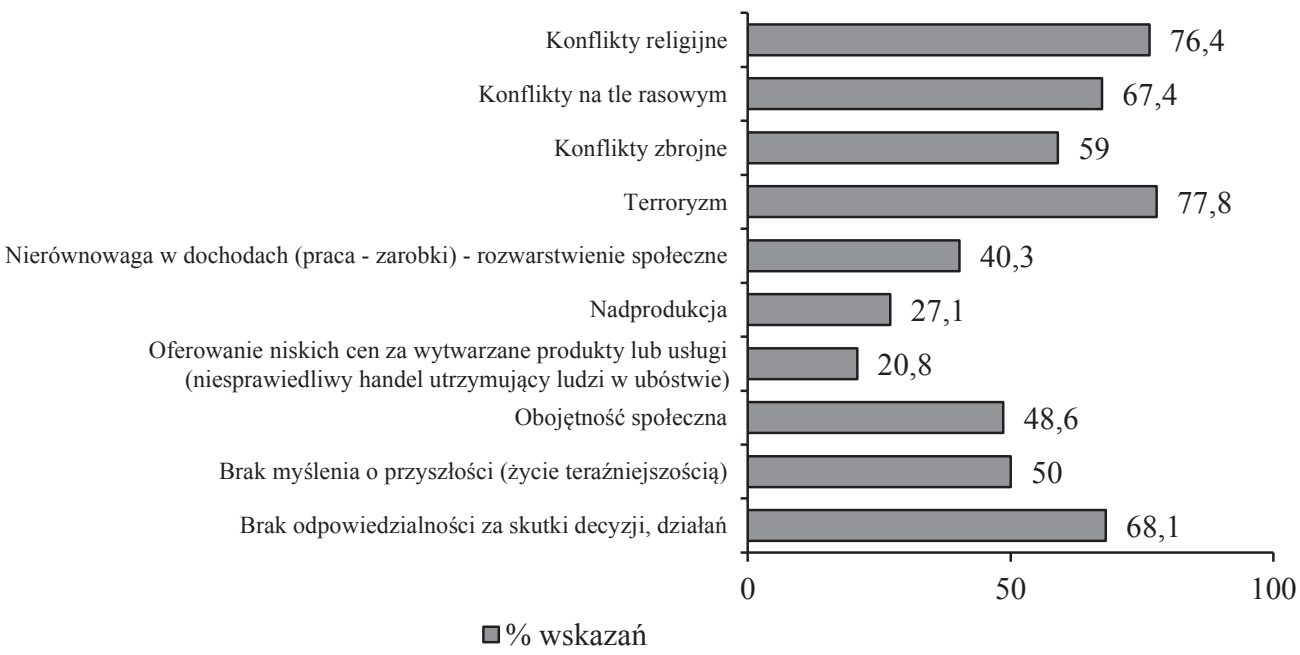

Rys. 3. Zagrożenia mogące zakłócić zrównoważony rozwój

Źródło: opracowanie własne na podstawie wyników badań.

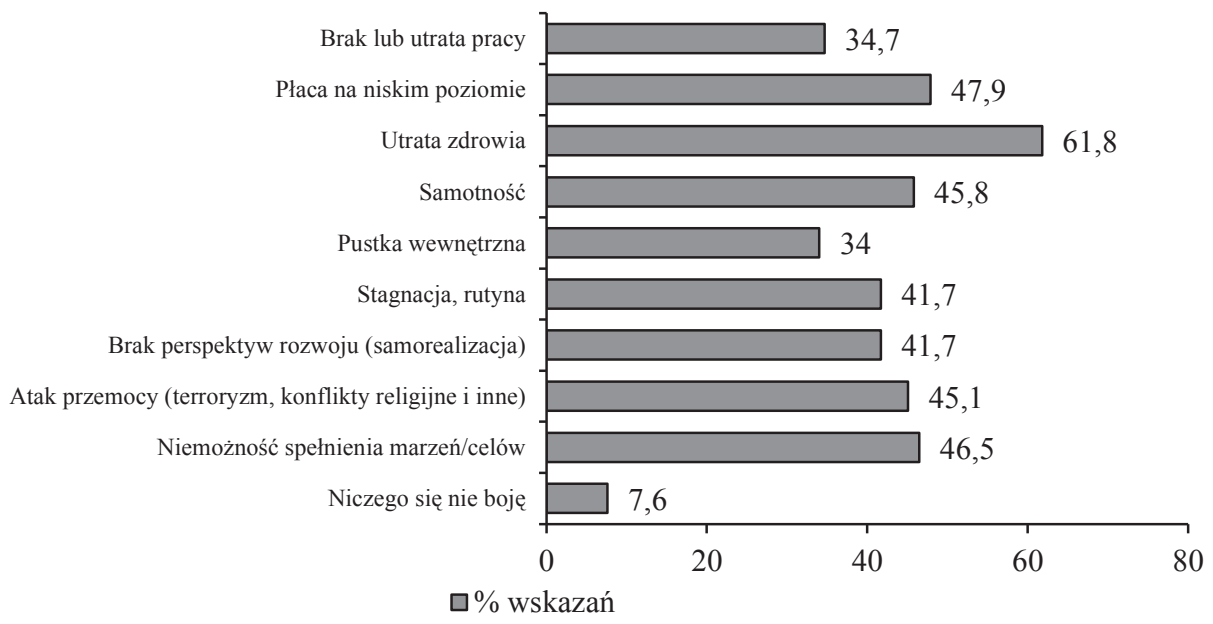

Rys. 4. Obawy młodych ludzi

Źródło: opracowanie własne na podstawie wyników badań.

wskazań - ich rozkład widoczny jest na rys. 4 . Niczego nie boi się tylko 7,6\% respondentów (najmniej wskazań). Obawy młodzieży nie są bezpodstawne, co zaprezentowano w teoretycznej części publikacji. Uzyskane odpowiedzi odzwierciedlają aktualną sytuację na świecie.

Z przeprowadzonych badań można wyciągnąć wniosek, że rozwój cywilizacyjny niesie zagrożenia, które w ostatnim czasie wzbierają na sile i powodują zachwianie w propagowaniu idei zrównoważonego rozwoju (w tym m.in. otwartości, do- 
stępności do edukacji, równych szans rozwoju, podnoszenia jakości życia). Na zdecydowane podkreślenie zasługują terroryzm i konflikty religijne - młodzi ludzie zauważają te problemy i wskazują je jako główne aspekty hamujące rozwój. Działania prospołeczne i prośrodowiskowe przynoszą korzyści, ale jak wynika z rozkładu wskazań respondentów, nie są wystarczające (nie są szansą dla rozwoju) wobec wyzwań, jakie niosą wskazane przez ankietowanych zagrożenia. Nadzieję na zrównoważony rozwój przynosi ludzka kreatywność - postawa ta, rozumiana pozytywnie, stawia człowieka w centrum wszechświata (antropocentryzm). Człowiek, jak można wnioskować, jest i nadal będzie odgrywał kluczową rolę w kreowaniu jakości życia na Ziemi. Jakość życia i zdrowie są według ankietowanych priorytetowe dla rozwoju populacji, jednak wobec problemów w kwestii nasilających się konfliktów na tle religijnym i rasowym czy dostępu do usług medycznych stają się jeszcze większym wyzwaniem dla obecnego i przyszłych pokoleń. Niestety respondenci nie powiązali dążenia do bezpieczeństwa i zaangażowania w sprawy społeczne jako kwestii, które mogą pomóc w utrzymaniu pokoju na świecie - zarówno pierwszy, jak i drugi element wiążą się z propagowaniem postaw proekologicznych.

Najbardziej równomierny rozkład odpowiedzi pojawił się w bloku odnoszącym się do najważniejszych elementów zrównoważonego rozwoju oraz zagadnień dotyczących obaw młodych ludzi. Najbardziej zróżnicowany rozkład wskazań zaobserwowano w kwestii szans rozwojowych. Najwięcej wskazań ze wszystkich bloków tematycznych uzyskała ludzka kreatywność (szansa na rozwój) - 82,6\%. Najmniej wskazań uzyskała odpowiedź: niczego się nie boję (obawy) - 7,6\% oraz dążenie do bezpieczeństwa (szanse rozwojowe) - 21,5\%.

\section{Zakończenie}

Badania ilustrują, jak istotną funkcję pełnią w życiu młodego człowieka relacje pomiędzy ludźmi, komfort życia oraz tzw. work-life balance. Ankietowani zdają się być przy tym świadomi, że zrównoważony rozwój wymaga połączenia ze sobą wielu elementów - dopiero ich synergia zapewnia wymierny efekt. Świadczyć o tym może bardzo zbliżony odsetek wskazań większości elementów: równych szans rozwoju dla kobiet i mężczyzn, wykorzystania nowych technologii i odnawialnych źródeł energii, recyklingu czy racjonalnego gospodarowania zasobami naturalnymi. Niewielkie różnice procentowe mogą oznaczać trudności z dokonaniem wyboru wyłącznie jednego $\mathrm{z}$ aspektów. To z kolei może wynikać z powszechnej dziś interdyscyplinarności - młodzi ludzie są świadomi, że wielu fenomenów - nie tylko naukowych - nie sposób rozpatrywać jako zjawiska odrębne, lecz jako połączone - wiele czynników nakłada się na siebie, by ostatecznie tworzyć wspólną wartość. Kreatywność ludzka, uznana przez respondentów za kluczową dla przyszłości, postrzegana jest jako element pozytywny. Zagrożenia wynikające $\mathrm{z}$ różnic religijnych i aktów terroryzmu mogą w największym stopniu zakłócić dążenie do zrównoważonego rozwoju. Kreowanie zrównoważonej przyszłości nie jest jednak, zdaniem responden- 
tów, związane z dążeniem do bezpieczeństwa. Można jednak mieć nadzieję, że kreatywność pomoże w eliminowaniu działań związanych z agresją.

Rodzą się kolejne pytania: Jak będzie wyglądał świat w przyszłości? Czy gromadzona wiedza pomoże człowiekowi ustrzec się przed samozniszczeniem? Czy systemy oparte na wzajemnym zrozumieniu, poszanowaniu, odpowiedzialności (ekologizacja) wyprą te, które szerzą nienawiść i destrukcję? Które emocje będą miernikiem kreowania przyszłości? Stawiane pytania badawcze zachęcają do podejmowania kolejnych rozważań związanych ze zrównoważonym rozwojem.

\section{Literatura}

Borkowska S., 2010, Równowaga między praca a życiem pozazawodowym, Acta Universitatis Lodziensis, No. 240, s. 5-44.

Cash D.W., Clark W.C., Alcock F., Dickson N.M., Eckley N., Guston D.H., Jäger J., Mitchell R.B., 2003, Knowledge systems for sustainable development, PNAS, Vol. 100, No. 14, s. 8086-8091.

Delecta P., 2011, Review article. Work-life balance, International Journal of Current Research, Vol. 3, No. 4, s. 186-189.

Dubiński J., 2013, Zrównoważony rozwój górnictwa surowców mineralnych, Journal of Sustainable Mining, Vol. 12, No. 1, s. 1-6.

Gawlik R., 2015, Zmiany parametrów jakości życia młodych Europejczyków - implikacje dla przedsiębiorstw, MPRA, No. 67091, posted 6, s. 1-12.

Górka K., 2007, Wdrażanie koncepcji rozwoju zrównoważonego i trwałego, Ekonomia i Środowisko, nr 2(32), s. 8-20.

http://wiadomosci.onet.pl/swiat/zamachy-terrorystyczne-w-ostatnich-latach-infografika/p6cpkzg (31.12.2017).

http://www.un.org/sustainabledevelopment/blog/2015/12/sustainable-development-goals-kick-offwith-start-of-new-year/ (01.12.2017).

https://www.hbrp.pl/b/work-life-balance---tu-nie-chodzi-o-rownowage/DQ725mbo (15.12.2017).

Jaźwińska D., 2016, Efektywność strategii zrównoważonego rozwoju, Zeszyty Naukowe Politechniki Poznańskiej - seria Organizacja i Zarządzanie, nr 71, Poznań, s. 151-164.

Jaźwińska D., 2017, Odpowiedzialność w kontekście zrównoważonego rozwoju przedsiębiorstwa, [w:] Zajkowska M. (red.), Potencjat innowacyjny i marketingowy wspótczesnych przedsiębiorstw, Prace Naukowe Wyższej Szkoły Bankowej w Gdańsku, t. 49, Gdańsk, s. 97-110.

Judy R.W., D’Amico C., 1997, Workforce 2020. Work and Workers in the 21st Century, Hudson Institute, Indianapolis Indiana.

Keith N., 2008, Corporate Social Responsibility. An international perspective, World Focus, Vol. 9, No. 3, s. 20-29.

Kiyosaki R.T., Lechter S.L., 2001, Kwadrant przepływu pieniędzy, Instytut Praktycznej Edukacji, Osielsko.

Komunikat Komisji do Parlamentu Europejskiego, Rady, Europejskiego Komitetu Ekonomiczno-Spotecznego i Komitetu Regionów. Odnowiona strategia UE na lata 2011-2014 dotycząca społecznej odpowiedzialności przedsiębiorstw, 2011, Komisja Europejska, Komunikat nr 681.

Kot W., 2003, Historyczny przeglad orientacji filozoficznych, Wydawnictwo Akademii Ekonomicznej w Poznaniu, Poznań.

Kozioł L., Wojtowicz A., 2016, Wybrane praktyki zarządcze a dobrostan pracowniczy, Zeszyty Naukowe Politechniki Poznańskiej - seria Organizacja i Zarządzanie, nr 71, Poznań, s. 165-177. 
Kramer J., 2011, Konsumpcja - ewolucja ról i znaczeń, Konsumpcja i Rozwój, nr 1, s. 5-15.

Leśniak-Łebkowska G., 2017, Drabina zaufania i kapitat społeczny jako podstawy rozwoju zarzadzania strategicznego przedsiębiorstwem $w$ XXI wieku, Studia Oeconomica Posnaniensia Vol. 5, No. 9, s. 50-68.

Lockwood N.R., 2003, Work/Life Balance. Challenges and Solutions, SHRM Research, s. 1-12.

Łuczka W., 2016, Zrównoważona konsumpcja i uwarunkowania jej rozwoju, Handel Wewnętrzny, nr 6(365), s. 136-145.

Matten D., Moon J., 2004, Corporate Social Responsibility Education in Europe, Journal of Business Ethics, No. 54, s. 323-337.

Porter M.E., Kramer M.R., 2011, Creating shared value, Harvard Business Review, January-February, s. $4-17$.

Report of the World Commission on Environment and Development: Our Common Future, 1987.

Rohatyński R., 2017, Wplyw postaw menedżerów na decyzje prognostyczne, [w:] Zajkowska M. (red.), Zarzadzanie przedsiębiorstwem $w$ warunkach zmienności otoczenia, Prace Naukowe Wyższej Szkoły Bankowej w Gdańsku, t. 50, Gdańsk, s. 117-132.

Ross A., 2017, Świat przyszłości. Jak nastęna fala innowacji wplynie na gospodarkę, biznes i nas samych, MT Biznes, Warszawa.

Sachs J.D., 2012, From Millennium Development Goals to Sustainable Development Goals, The Lancet, Vol. 379, No. 9832, s. 2206-2211.

Stefanowicz T., 1996, Wstęp do ekologii i podstaw ochrony środowiska, Politechnika Poznańska, Poznań.

Tai F.-M., Chuang S.-H., 2014, Corporate Social Responsibility, iBusiness, No. 6, s. 117-130.

Teneta-Skwiercz D., 2017, Wybrane koncepcje biznesowe wobec problemu ubóstwa na świecie, [w:] Zajkowska M. (red.), Zarządzanie przedsiębiorstwem w warunkach zmienności otoczenia, Prace Naukowe Wyższej Szkoły Bankowej w Gdańsku, t. 50, Gdańsk, s. 47-60.

Waas T., Verbruggen A., Wright T., 2010, University research for sustainable development: Definition and characteristics explored, Journal of Cleaner Production, No. 18, s. 629-636.

Williams C.C., Millington A.C., 2004, The diverse and contested meaning of sustainable development, The Geographical Journal, Vol. 170, No. 2, s. 99-104.

Więcek-Janka E., Wyrwicka M.K., Jaźwińska D., Loera M.R.C., 2017, Application of the postulates of sustainable development in family business in the light of empirical research, [w:] Nalepka A., Ujwary-Gil A., (red.), Business and Non-Profit Organizations Facing Increased Competition and Growing Customers' Demands, Vol. 16, Wyższa Szkoła Biznesu-National-Louis University in Nowy Sącz, Nowy Sącz, s. 441-453.

Wyrwicka M., Jaźwińska D., 2015, EMAS jako narzędzie implementacji zrównoważonej produkcji, Logistyka, nr 3, CD 2, s. 5853-5858. 